\title{
Is it the school of fish or the size of the pond that matters? An experimental examination of reference group effects in secondary school
}

\author{
Christoph Zangger ${ }^{1}$, Sandra Gilgen ${ }^{1}$, Nora Moser ${ }^{1}$ \\ ${ }^{a}$ University of Zurich, Andreasstrasse 15, 8050 Zurich, Switzerland \\ ${ }^{b}$ University of Bern, Fabrikstrasse 8, 3012 Bern, Switzerland \\ ${ }^{c}$ University of Bern, Fabrikstrasse 8, 3012 Bern, Switzerland
}

\begin{abstract}
It has often been suggested that reference group effects in education work through the self-concept of pupils. At the same time, it has been shown that teachers compare students with their peers when making evaluations. This observation gives rise to an alternative explanation of reference group effects on educational attainment: When deciding whether or not to recommend a student for grammar school, teachers consider not only the individual student's performance and abilities but use the wider group of motivated students as a frame of reference. Thus, given the limited number of places available in grammar school, a student's chances of being recommended also depend on his or her standing in the performance distribution as well as on the number of competitors. Using choice experiments presenting groups of three to five students to secondary school teachers in Switzerland, we show how the individual probability for a grammar school recommendation depends on the size of the reference group. Furthermore, individual chances are especially affected by the number of other students in the group that the teacher perceives as fit for grammar school. Our findings point towards a competition effect: The more and the better the competitors, the smaller the individual chances. In this respect, it seems better to be a big fish in a small pond.

Keywords: Reference Group Effects, Teacher Recommendation, Choice Experiment, Group Size, Compositional Effects
\end{abstract}

${ }^{*}$ Corresponding author 


\section{Introduction}

There is general agreement on the importance of educational transitions for explaining persistent inequalities in education. In this regard, many have advocated for explanations in terms of intended and unintended consequences of purposive social actions made by relevant agents, such as students, their parents and teachers (e.g., Becker, 2003; Boone and Van Houtte, 2013; Breen and Goldthorpe, 1997; Erikson and Jonsson, 1996; Stocké, 2007). A second line of research suggests that one's educational performance and attainment is also affected by the academic behavior and achievement of others, particularly by one's peers (e.g., Alexander and Campbell, 1964; Hanushek et al., 2003; Imberman et al., 2012; Sacerdote, 2001, 2011; Zimmerman, 2003). While the former line of research points to a social (and ethnic as well as a gender) gradient in students' educational opportunities, the latter stresses reference-group effects caused by the social and academic composition of the student body (e.g., Alexander and Eckland, 1975; Marsh and Parker, 1984; Thrupp et al., 2002). Surprisingly, a key actor who links these two dimensions of educational inequalities has yet received relatively little attention: the teacher and his or her role in the allocation process. This paper tries to close this gap. More specifically, we elaborate an alternative explanation for the finding that being surrounded by high-achieving peers can be detrimental to students' educational chances. This has predominantly been discussed as Big-Fish-Little-Pond (BFLP) effects in the literature (Alicke et al., 2010; Davis, 1966; Marsh and Parker, 1984; Marsh, 1987; Marsh and Hau, 2003). Instead of focusing on students' selfconcept or social learning from peers, we ask how reference group effects and relative comparison processes shape teachers' decisions regarding the recommendation of students for grammar school in Switzerland. This approach comes with the advantage that individual actions of teachers are directly observable. Moreover, the literature on reference group effects mainly focuses on different compositional aspects such as the achievement of peers (e.g., Gröhlich and Guill, 2009; Huguet et al., 2009; Trautwein et al., 2006) and has largely neglected the second aspect of the BFLP effect: the size of the pond (Alicke et al., 2010; Zell and Alicke, 2009). Against the background of an ever increasing literature discussing the influence of class size on individual educa- 


\footnotetext{
${ }^{1}$ Those who are not recommended for grammar school can take additional exams and be granted admission if they pass.
}

al outcomes (e.g., Krueger, 1999; Wyse et al., 2008), this comes as an even bigger surprise. We therefore also examine whether being part of a larger group of competitors also has a detrimental effect on one's educational chances. To investigate whether teachers are affected by reference group effects in their judgements of the fitness of pupils for grammar school, we collected data from (prospective) teachers using choice experiments in the city of Bern, Switzerland (Street and Burgess, 2007). In this setting, recommendations for grammar school are of special interest, since they enable a direct access to the most advantageous school track in the Swiss school system without further examination. ${ }^{1}$

The results indicate that teachers base their recommendation decisions not only on students' individual characteristics but also on the wider group context. Independent of individual academic performance and effort, being part of a larger group reduces one's chances for a grammar school recommendation. Moreover, this effect seems to work primarily through the share of recommended classmates: The higher the share of peers with a recommendation, the lower a pupil's chances for being likewise recommended.

The remainder of this paper is organized as follows: The next section briefly outlines the theoretical arguments and reviews the state of the art. The third section presents the data and (experimental) methods used to test the hypotheses. The results are presented in the fourth section. The paper concludes by placing the main findings in context with the literature and by discussing the implications in terms of educational opportunities in tracked education systems.

\section{Background}

Ever since Davis' (1966) Frog-Pond, Marsh and Parker's (1984) Big-Fish-LittlePond (BFLP) effects and the Wisconsin model of status attainment (Sewell et al., 1969; Haller and Portes, 1973), sociologists and other social scientists have extensively studied the effects of classroom composition on individual educational attainment (for a compact summary see Sacerdote, 2011). In the following, we first briefly summa- 
rize existing literature on compositional influences before then focusing on the role of teachers in the explanation of such effects. We particularly focus on the role of the size of the reference group for individual educational chances.

Regarding compositional effects, there is considerable agreement that facing highachieving peers has a negative effect on a pupil's academic self-concept and thus on individual achievement (e.g., Gröhlich and Guill, 2009; Huguet et al., 2009; Marsh and Hau, 2003; Sacerdote, 2001; Trautwein et al., 2006). However, effects vary not only with the methods used (e.g., experimental vs. observational studies) but also with different measures of academic performance (e.g., Zimmerman, 2003; Dockx et al., 2019). At the same time, and although social status and educational attainment are closely related (Becker, 2003; Breen and Goldthorpe, 1997), the average social status of the student body is reported to have an independent, additional positive effect on individual attainment (e.g., Maaz et al., 2008; Palardy, 2008; Rumberger and Palardy, 2005; Palardy, 2008). However, this evidence largely refers to theories in which the social composition of peers as well as their performance levels and behaviour influence individual achievement and attainment e.g., through social learning processes. In the present study, however, we are especially interested in the moderating effect of a shared teacher.

In addition to the documented effects of students' social and ethnic background on teachers' evaluations (e.g., Boone and Van Houtte, 2013; Jussim and Harber, 2005; Rist, 1970), it has been suggested that, like their pupils, teachers could be affected by comparison processes (Trautwein et al., 2006; Boone et al., 2018). Comparing grades with more objective measures, such as test scores, it becomes apparent that the classroom context clearly structures teachers' evaluations of their students (Hoge and Coladarci, 1989; Maaz et al., 2008). Thus, students' grades can be seen as a reflection of a reference group effect in which teachers evaluate a particular student's academic performance according to how it fares in comparison with the achievement of others. With data from Flanders, Boone and colleagues (2018) show that teachers do use a classroom's composition as a frame of reference. However, while the ethnic and social composition have no effect, the ability composition of students significantly influences teachers' transition recommendations. In line with a relative advantage or social com- 
petition explanation, the authors find a larger likelihood for low-ability students to be recommended for an academically orientated track when facing a group of low-ability compared to high-ability peers (Boone et al., 2018). However, since this result is based on cross-sectional data, we don't know whether this effect of the class composition on teacher recommendations is causal. To uncover the underlying social mechanisms, we need to examine this further using methods that allow for causal inference.

Acknowledging that the reference group can have an effect on teachers' decisions, gives us a competing explanation for the direct compositional effects of the achievement and status of peers on individual academic outcome. Rather than through the adjustment of a pupil's self-concept to the observed academic performance of peers, classroom composition could alternatively work through the teacher. With the classroom as a point of reference, teachers might make context-dependent evaluations of the individual peers. If teachers are to recommend the best pupils for grammar school, they must automatically consider a student's position in the performance distribution of the wider group of competitors. We therefore hypothesize that teacher recommendations for grammar school depend on the composition of the student body. More precisely, we expect the presence of high-achieving peers to have a negative effect on individual chances of receiving a grammar school recommendation (i.e., through invidious comparison effects; Sacerdote, 2011). Furthermore, since each classroom acts as an individual frame of reference and thus shapes teachers' perceptions of their students, we expect recommendation decisions to vary between teachers.

Finally, the probability for a recommendation might also depend on the number of competitors, i.e., the size of the group of students who would also like to attend grammar school. Although not directly applicable for the present purpose, existing studies suggest (small) negative effects of large class sizes on individual educational attainment (Krueger, 1999; Wyse et al., 2008). More relevant for this study, however, Zell and Alicke (2009) as well as Alicke et al. (2010) demonstrate that reference group effects are particularly relevant in small groups. One's standing in the immediate context of a smaller comparison group is more weighty for self-evaluations than comparisons with larger groups. If reference group effects on teacher decisions follow a similar logic, we would also expect them to be stronger in smaller groups. However, since there has 
been a more or less fixed number of available places in grammar schools throughout the last 30 years in Switzerland (Federal Statistical Office, 2017), it is probable that teachers take the 'demand side' of grammar schools into account and fill up places accordingly. Because of this, we hypothesize that the individual propensity for a recommendation diminishes with an increasing number of peers who also have grammar school ambitions. We would expect this effect to be especially strong when teachers evaluate the potential of these peers highly and recommend them for grammar school. That is, we assume the negative effect of a larger number of ambitious peers to be more pronounced if the teacher recommends them for grammar school.

Summing up, we argued that teachers act as mediators for the effects of classroom composition on a student's probability of getting a grammar school recommendation. More specifically, because of the comparisons a teacher is bound to make, we expect that a student's chances decrease when his or her peers are high-performing. Additionally, because there is a more or less fixed number of places in grammar school, we expect the size of the group of students in each class who want to attend grammar school to affect individual chances. As in any competitive situation, we would thus assume that being part of a larger, stronger group decreases the individual probability of being on top and, in this context, of securing a place in grammar school. Finally, since teachers have their individual sets of beliefs and attitudes, we expect significant differences between teachers in their recommendation decisions.

\section{Data and Methods}

The data used to examine reference group effects on teacher recommendations for grammar school were collected in a small survey of (prospective) secondary school teachers in Bern, Switzerland. In this survey, respondents were confronted with three different groups of students belonging to different hypothetical classes and all of whom want to attend grammar school in $9^{\text {th }}$ grade. In total, 70 teachers participated in the study, and evaluated a total of 840 hypothetical students ${ }^{2}$. The different sets of students

\footnotetext{
${ }^{2}$ This number reduces to 68 teachers and 816 hypothetical students after deleting cases with missing values.
} 


\begin{tabular}{|c|c|c|c|c|}
\hline & Tom & Sarah & Lisa & Marc \\
\hline Grade last semester (math) & 5 & 5.5 & 4.5 & 5.5 \\
\hline $\begin{array}{l}\text { Development of } \\
\text { educational performance } \\
\text { (compared with previous } \\
\text { term) }\end{array}$ & Better than before & Same as before & Worse than before & Same as before \\
\hline Participation during class & $\begin{array}{l}\text { Actively contributes } \\
\text { during class }\end{array}$ & $\begin{array}{l}\text { Contributes only } \\
\text { rarely during class }\end{array}$ & $\begin{array}{l}\text { Contributes only } \\
\text { rarely during class }\end{array}$ & $\begin{array}{l}\text { Actively contributes } \\
\text { during class }\end{array}$ \\
\hline Pace of learning & $\begin{array}{l}\text { Sometimes takes } \\
\text { more time to learn } \\
\text { new things }\end{array}$ & $\begin{array}{l}\text { Learns new things } \\
\text { easily }\end{array}$ & $\begin{array}{l}\text { Sometimes takes } \\
\text { more time to learn } \\
\text { new things }\end{array}$ & $\begin{array}{l}\text { Learns new things } \\
\text { easily }\end{array}$ \\
\hline Learning habits & $\begin{array}{l}\text { Has trouble focusing } \\
\text { and often needs } \\
\text { assistance }\end{array}$ & $\begin{array}{l}\text { Has no trouble } \\
\text { focusing and can } \\
\text { figure things out for } \\
\text { herself/himself }\end{array}$ & $\begin{array}{l}\text { Has trouble focusing } \\
\text { and often needs } \\
\text { assistance }\end{array}$ & $\begin{array}{l}\text { Has no trouble } \\
\text { focusing and can } \\
\text { figure things out for } \\
\text { herself/himself }\end{array}$ \\
\hline $\begin{array}{l}\text { Parental educational } \\
\text { background }\end{array}$ & $\begin{array}{l}\text { Attended grammar } \\
\text { school }\end{array}$ & $\begin{array}{l}\text { Did not attend } \\
\text { grammar school }\end{array}$ & $\begin{array}{l}\text { Did not attend } \\
\text { grammar school }\end{array}$ & $\begin{array}{c}\text { Attended grammar } \\
\text { school }\end{array}$ \\
\hline $\begin{array}{l}\text { His/her parents would like } \\
\text { their child to... }\end{array}$ & $\begin{array}{c}\text {...complete grammar } \\
\text { school }\end{array}$ & $\begin{array}{c}\ldots . . \text { complete a } \\
\text { vocational degree }\end{array}$ & $\begin{array}{c}\text {...complete grammar } \\
\text { school }\end{array}$ & $\begin{array}{c}\text {...complete a } \\
\text { vocational degree }\end{array}$ \\
\hline $\begin{array}{l}\text { Grammar school } \\
\text { recommendation }\end{array}$ & $\square$ & $\square$ & 口 & 口 \\
\hline
\end{tabular}

Figure 1: Sample vignette of hypothetical students wishing to attend grammar school

were constructed as D-efficient fractional factorials which were then used to construct different choice-sets of three different group sizes (3 vs. 4 vs. 5 students; relative Defficiency 95.71; Street and Burgess, 2007). Table 1 depicts all characteristics of the experimental setting. A sample vignette of four students is depicted in Figure 1. Each teacher was presented with three such vignettes, one of each group size. To circumvent potential learning effects, the order of the vignettes was also randomly altered: Some teachers were first confronted with the small group of three students and others first evaluated the larger group of five students.

Since a recommendation for grammar school should reflect an assessment of a student's future potential rather than prior performance (Erziehungsdirektion des Kantons Bern, 2017), grades and especially their development in the course of the year before are key information for teachers' decisions (in the same vein, Klapproth and Fischer (2018) recently used a similar methodological approach to demonstrate that the teachers' recommendation decisions are shaped by the development of students' GPAs). In the Swiss education system, grades range from 1 , the worst, to 6 , the best. The grade 4 equals a 'pass', 5 is considered a 'good' mark and 5.5 is given for a 'very good' achievement. Grades range from 4.5 to 5.5 in the experimental design. The highest grade is overrepresented since only students with a good to excellent performance are 
expected to attend the most demanding track of the Swiss education system, the grammar school. The highest mark was not used in the design, since it would probably have been an overriding argument for grammar school. Characteristics that are so potent are a threat to survey experiments since respondents might fail to even register the values of the other treatments in their evaluations and this could lead to biased results.

Moreover, apart from cognitive ability, teachers are also asked to take students' learning habits, as well as their general classroom behaviour into consideration. To account for this, the choice experiment provides the respondents with information on students' participation during class, the pace with which they learn new things and their study habits. While the students themselves are all characterized as highly motivated to attend grammar school, we randomly altered parental aspirations as well as their educational background as part of the experimental setup. Finally, we also accounted for twoway interactions in the design of the fractional factorial, such that our experimental design also allows us to estimate interaction effects between the included dimensions.

Furthermore, additional data on respondents, in particular their teaching experience (Figure A1 in the appendix), knowledge about the recommendation process, and individual social and migration background were also collected as a part of the paper and pencil survey. Although almost all of the respondents have at least some teaching experience, it should be noted that they have not yet finished their teacher education for secondary school. This can certainly be regarded as a challenge for a straightforward generalization of the results beyond the collected sample. However, since a critical debate on selectivity in education and on how contextual factors, such as social origin, influence the educational opportunities of students are part of the teacher education curriculum, respondents might have an idea of how the reference group of a student affects his or her outcomes. One could thus argue that such effects would be even more pronounced in real-world classrooms in which this theoretical knowledge is slowly replaced by everyday practices and routines. However, as with any experiment, one should nevertheless be careful when interpreting and generalizing the results.

To create a more lifelike situation, which is important for the validity of an experiment, we made a slight adjustment to the traditional choice experiment. Instead of picking one student, respondents were asked to make an individual recommendation 


\begin{tabular}{ll}
\hline \hline Characteristics & Values \\
\hline Students' characteristics & \\
Gender & 0 Male, 1 Female \\
Grade last semester & $4.5,5.0,5.5$ \\
Performance & 0 better, 1 about the same, 2 worse than before \\
Participation during class & 0 active, 1 not active \\
Learning and study habits & 0 learns new things easily, 1 needs some time \\
Methods and learning style & 0 independent \& concentrated, 1 not very ind. \& c. \\
Parental education & 0 attended grammar school, 1 didn't attend it \\
Parental aspirations & 0 grammar school, 1 vocational training \\
Further classroom context & \\
Group size & $3,4,5$ \\
Subject & 0 math, 1 German \\
\hline \hline
\end{tabular}

Table 1: Characteristics in the experimental setting

for each pupil. This slight adaptation was made to accommodate for the fact that the real-life problem is that of a choice but not necessarily of just one pupil. Teachers are expected to recommend all students they think have the potential to successfully complete grammar school. As previously mentioned, the experiment was set up as a D-efficient choice experiment. This yielded a fractional factorial design with optimally balanced and orthogonal arrays, which allows us to estimate the causal effect of the randomly altered characteristics on the outcome of interest (Street and Burgess, 2007). A consequence of this design is that each vignette (student) can be treated as an individual observation. This allows us to analyze the binary outcome (recommendation: yes/no) using multilevel logistic regression models with the share of other recommended students and further compositional characteristics as right-hand side variables (Allison, 2009; Hox, 2010). Thus, we consider the model

$$
\boldsymbol{Y}=\alpha+\boldsymbol{X} \boldsymbol{\beta}+\eta_{j}+\varepsilon_{i j}, \quad i=1, \ldots, n_{j}, j=1, \ldots, J
$$

where $i$ denotes the hypothetical student portrayed in the vignette and $j$ is the index of the teacher making a recommendation. On the one hand, the matrix $\boldsymbol{X}$ depicts observed characteristics of both the hypothetical students seeking a recommendation (i.e., the characteristics in Table 1) and observed teacher background characteristics 
(e.g., their experience, gender, social and ethnic background). The vector of the corresponding effects is denoted by $\boldsymbol{\beta}$. On the other hand, $\eta_{j}$ captures the variance at the teacher level, that is, the extent to which teachers differ in their decision making (e.g., due to unobserved attitudes and beliefs about a particular student). Since the outcome (recommendation for grammar school) is a binary variable, one might consider a binary logistic or probit model with clustered standard errors to account for multiple observations (hypothetical students) per teacher (Wooldridge, 2003). However, from a theoretical as well as an econometric point of view, we are interested in the extent to which teachers differ in their recommendation decisions. Since the respondents in our sample can be regarded as a random sample from the wider population of (prospective) secondary school teachers, we could treat $\eta_{j}$ in equation (1) as random and thus opt for a random effects model (Allison, 2009; Clarke et al., 2015). The first row of Table 2 reports the result of a likelihood ratio test comparing our baseline random effect model (without controlling for additional teacher characteristics; model 1 in Table 3) to the corresponding ordinary binary logistic regression model (model 1 in Table A2 in the appendix). The corresponding $\chi^{2}$ value significantly exceeds the expected value of 1

\begin{tabular}{lcr}
\hline \hline Test & Test statistic (df) & $p$-value \\
\hline Logit vs. random effects (LR) & $28.43(1)$ & 0.000 \\
Random vs. fixed effects (Hausman) & $1.35(5)$ & 0.930 \\
\hline \hline
\end{tabular}

Table 2: Testing different model specifications

for no difference between the two models. Thus, the random effect model fits the data considerably better than a common binary logistic regression model. While a random effect model seems to be the better choice in the present case, it is only adequate if the random effect is uncorrelated with the individual error term (Wooldridge, 2010; Clarke et al., 2015). To test this assumption that $\eta_{j}$ is independent of $\epsilon_{i j}$, we use the well-known Hausman test that allows us to assess whether the random and the fixed effects estimates both target the same values of $\beta$ (i.e., we test the null hypothesis that $E\left[\hat{\boldsymbol{\beta}}_{R E}\right]=E\left[\hat{\boldsymbol{\beta}}_{F E}\right]=\boldsymbol{\beta}$; Clarke et al., 2015). If the null hypothesis is rejected, we conclude in favour of a fixed effect model that removes the bias resulting from teacher selection effects (but which does not allow for the estimation of the effects of teacher 


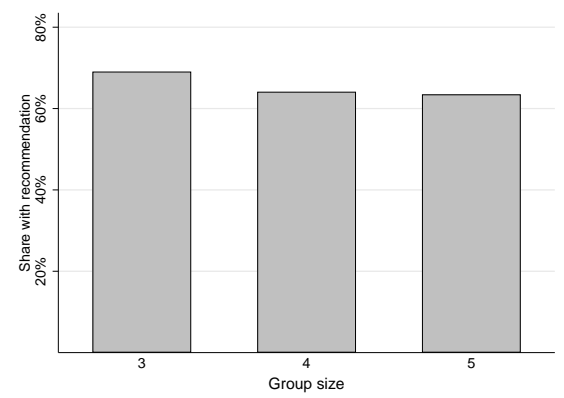

(a) By group size

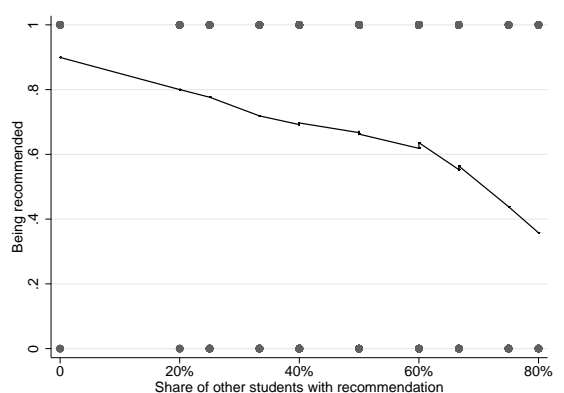

(b) By share with recommendation

Figure 2: Recommendation for grammar school by group size and share with recommendation

characteristics as a consequence). The second row of Table 2 reports the corresponding overall test statistic. The null hypothesis of this test states that the fixed effects model (which would result in unbiased estimates even if $\eta_{j}$ and $\epsilon_{i j}$ were correlated) and the random effects model both target the same values of $\beta$. With a value of 1.35 of the test statistic and an empirical $p$-value of 0.930 , we clearly fail to reject this null hypothesis. Consequently, we can use a random effect model. Descriptive statistics for all the variables included in the subsequent models can be found in the appendix (Table A1).

\section{Results}

We begin by looking at Figure 2 that shows the shares of recommended pupils by group size and share of other pupils with a recommendation. While group size does not seem to make such a difference, an individual student's likelihood of being recommended drastically sinks with the number of peers with a recommendation (Figure 2b). Together, the two bivariate associations are a first indication that teachers not only consider individual ability and traits of students but also form their decisions within the wider context of the reference group.

Moving on to the multivariate analyses, Table 3 depicts the results from binary logistic regression models with a teacher random effect. Effects are reported as average marginal effects (AME; Cameron and Trivedi, 2005). ${ }^{3}$ Starting at the bottom of

\footnotetext{
${ }^{3}$ As an additional robustness check, we present the results of the corresponding fixed effect models in
} 


\begin{tabular}{ccccc}
\hline \hline & $\begin{array}{c}(1) \\
\text { Baseline }\end{array}$ & $\begin{array}{c}(2) \\
\text { Controls }\end{array}$ & $\begin{array}{c}(3) \\
\text { Mediator }\end{array}$ & $\begin{array}{c}(4) \\
\text { Interaction }\end{array}$ \\
\hline Grade last semester & $0.543^{* * *}$ & $0.544^{* * *}$ & $0.479^{* * *}$ & $0.469^{* * *}$ \\
Participation (Reference: active) & $(0.011)$ & $(0.011)$ & $(0.023)$ & $(0.024)$ \\
not active & & & & \\
& $-0.085^{* * *}$ & $-0.085^{* * *}$ & $-0.079^{* * *}$ & $-0.078^{* * *}$ \\
Learning \& study habits (Reference: learns new & things easily) & $(0.022)$ \\
needs some time & $-0.071^{* *}$ & $-0.071^{* *}$ & $-0.064^{* *}$ & $-0.061^{* *}$ \\
& $(0.023)$ & $(0.023)$ & $(0.022)$ & $(0.022)$
\end{tabular}

\begin{tabular}{lcccc}
$\begin{array}{l}\text { Methods and learning style (Reference: independent } \\
\text { not very independent \& }\end{array}$ & $-0.185^{* * *}$ & $-0.185^{* * *}$ & $-0.173^{* * *}$ & $-0.171^{* * *}$ \\
rather not concentrated & $(0.023)$ & $(0.023)$ & $(0.023)$ & $(0.023)$ \\
Group size & $-0.025^{+}$ & $-0.026^{+}$ & -0.017 & -0.019 \\
& $(0.014)$ & $(0.014)$ & $(0.014)$ & $(0.013)$ \\
& & & $-0.400^{* * *}$ & $-0.462^{* * *}$ \\
Share classmates with recommendation & & $(0.094)$ & $(0.095)$ \\
Teacher: experience \& knowledge & $\checkmark$ & $\checkmark$ & $\checkmark$ \\
Teacher: background characteristics & $\checkmark$ & $\checkmark$ & $\checkmark$ \\
\hline \multicolumn{5}{l}{$\eta_{j}$} \\
& $1.122^{* *}$ & $0.999^{* *}$ & $2.567^{* * *}$ & $2.948^{* * *}$ \\
$\mathrm{~N}$ & $(0.392)$ & $(0.365)$ & $(0.839)$ & $(0.944)$ \\
\hline \hline
\end{tabular}

Marginal effects; Standard errors in parentheses

(d) for discrete change of dummy variable from 0 to 1

${ }^{+} p<0.1,{ }^{*} p<0.05,{ }^{* *} p<0.01,{ }^{* * *} p<0.001$

Table 3: Random effect models (being recommended for grammar school)

Table 3, the significant random effect $\eta_{j}$ suggests that teachers differ in their respective judgements of a pupil's potential. Although the magnitude of the random effect is somewhat reduced when controls for observed teacher characteristics such as their experience, knowledge about the recommendation process or their social and ethnic background are added, the teachers seem to be additionally influenced by unobserved characteristics (comparing model 1 with model 2 in Table 3).

Regarding the influence of the randomly altered dimensions in the choice set, we

Table A3 in the appendix. The corresponding effects in Table A3 (reported as odds ratios) are in line with the results of the random effect models. So are the effects of the logit model with clustered standard errors in Table A2 in the appendix. 
first note that not all of the characteristics in the experimental design are significant predictors for a recommendation for grammar school. ${ }^{4}$ While this isn't surprising in the case of the subject (math or German), the missing influence of parental educational background, which in our case served as an indicator of social origin, and of their aspirations needs explaining. First, the absence of an influence of parental education and aspirations could be explained by the fact that students' own aspirations are held constant (they all want to attend grammar school). Second, since we included students' grades, primary effects of social origin are already captured in all models (Becker, 2003; Breen and Goldthorpe, 1997). A third explanation for the insignificant effects could be that the teachers-in-training are mindful of the processes leading to educational inequalities. Due to the information we have on the curriculum of our prospective teachers, we can expect them to know how social origin affects educational chances. Also, the operationalisation of parents' educational background as a binary variable indicating whether or not they have attended grammar school might be insufficient and the intention too evident for the participants. Another variable that surprisingly fails to have the expected effect is the development of students' educational performance (compared to the prior semester). The interaction of a student's grades with the development thereof is not significant either.

All the other characteristics in the experimental design are highly significant predictors for a grammar school recommendation. Moreover, the models fit the data well (the pseudo- $R^{2}$ of model 1 is 0.405 - see Table A2 in the appendix). As expected, we see that a student's performance, measured in grades, is a very important predictor for a teacher's decision. A unit change in a student's grade leads, on average, to an increase of 54 percentage points (p.p.) for the likelihood of receiving a recommendation for grammar school (model 1 and 2 in Table 3). By contrast, students who don't participate actively in class as well as those who take longer to learn new things have reduced chances of getting recommended for grammar school (9 and 7 p.p. respectively). Sim-

\footnotetext{
${ }^{4}$ The corresponding likelihood-ratio test comparing a model with all experimentally altered covariates to model 1 in Table 3 yields a $p$-value of 0.986 . The two models can be considered equivalent and we therefore only present the result of models that do not include these additional, insignificant covariates of the experimental design.
} 


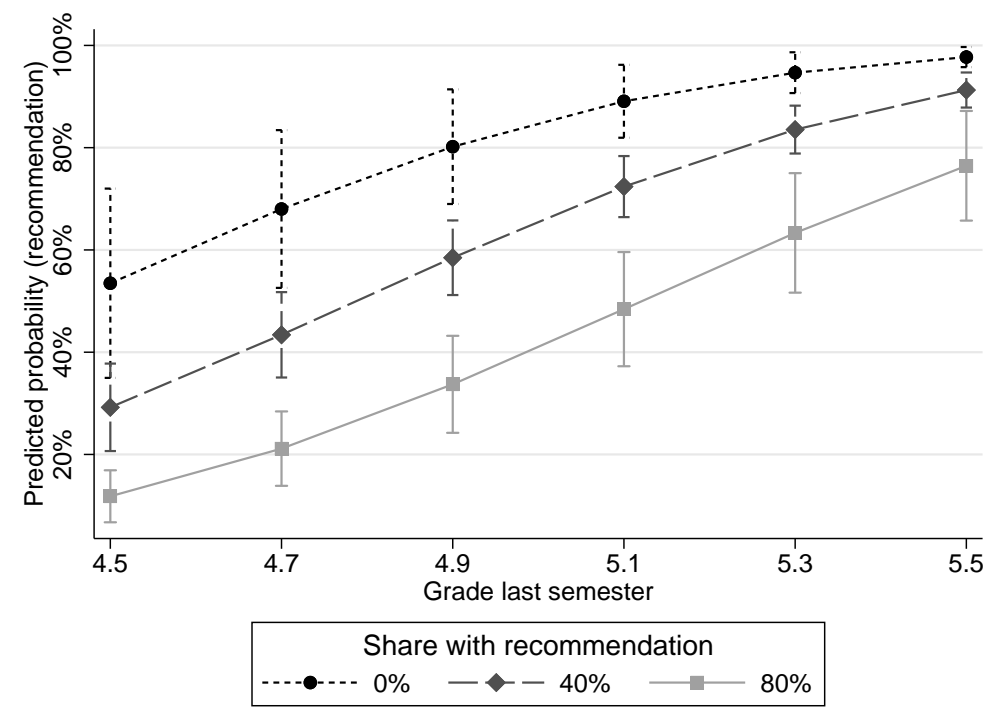

Figure 3: Share with a recommendation by grades

ilarly, teachers will be much less likely (19 p.p.) to recommend students who are not very independent and have trouble concentrating. However, what interests us most in the present context is how the number of students who also have grammar school ambitions affects individual chances. We see that there is indeed a slight marginally significant negative effect of 2.5 p.p. for each additional pupil in the baseline model. Comparing models 1 and 2 in Table 3, this effect, as well as all of the above mentioned, remains unchanged when we include the respondent-level control variables (e.g., respondents' experience as secondary school teachers or their social background).

However, if we go one step further and introduce the share of students with a recommendation, the effect sizes are generally reduced (model 3 in Table 3). Most importantly, the group size variable, reflecting the 'size of the pond', is no longer significant. Instead, the share of students with a recommendation has a strong negative effect on the individual chances of being recommended for grammar school. As indicated in Figure 3, this effect is strongest for students with grades around 5.0. This is worth highlighting since grades higher than 5.0 are often regarded as a necessary condition for a recommendation—although teachers are explicitly reminded not to base their rec- 


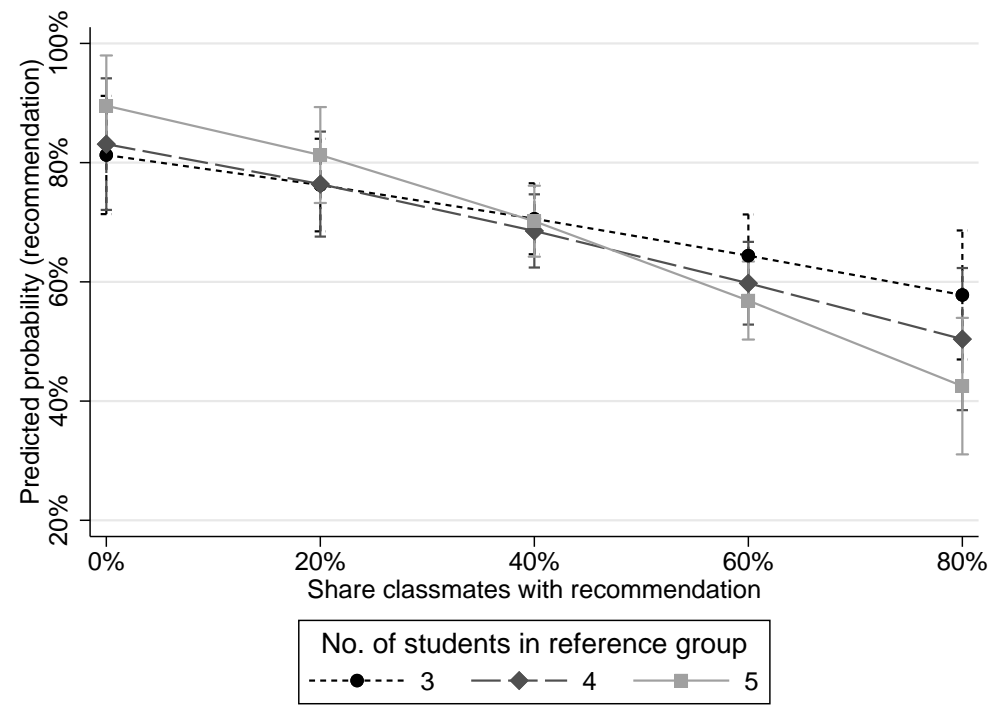

Figure 4: Interaction group size $\times$ share with recommendation

ommendation solely on such criteria as grades (Erziehungsdirektion des Kantons Bern, 2017). Unsurprisingly, for students who are characterized either with low or very high grades, the share of others with a recommendation does not matter that much. Nevertheless, there seems to be a tendency towards 'filling up empty places' even with students who do not perform that well if others are not recommended (indicated by the significant differences for students with grades lower than 5.0. in Figure 3).

The last random effect model in Table 3 includes an additional interaction term of the number of students seeking a recommendation (group size) with the share of students' with a recommendation. While the underlying coefficient (odds) is significant and negative, the corresponding average marginal effect is not reported in model 4 of Table 3 since the value of the interaction term cannot change independently of the values of its two component terms (Williams, 2012). To nevertheless assess the effect of this interaction, Figure 4 depicts the predicted probability of being recommended for grammar school for different group sizes by share of others with a recommendation. In this regard, we note that the negative effect of an increasing share of peers with a recommendation for grammar school is strongest in larger groups. On the other hand, 
if only a small number of students wish to attend grammar school, the share of those with a recommendation has a much smaller impact.

Summing up the presented evidence, it has been shown that teachers' decisions for or against a recommendation for grammar school are not only influenced by a student's effort and educational achievement but also by his or her peers. Such relative comparison processes influencing the evaluative decisions of teachers can be viewed as an alternative explanation for the often documented peer effects on educational attainment in general (Sacerdote, 2011) and the Big-Fish-Little-Pond effect in particular (Marsh and Parker, 1984). Our findings show that the number of ambitious peers reduces individual chances of a grammar school recommendation. We have further seen that this effect is mediated by the share of pupils the teacher deems fit for grammar school. Figuratively speaking, it is not only the size of the pond that matters but also how good the other fish are. Individual chances are lowest for a student in a big group with strong peers. As in any competition, the more competitors one has and the better they are, the harder it is for an individual to win the race. In our example securing a scarce and coveted spot in grammar school is harder for pupils in academically strong classrooms.

\section{Discussion and Conclusion}

This paper proposed an alternative mechanism for peer group effects (e.g., Sacerdote, 2011; Zimmerman, 2003), such as the Big-Fish-Little pond effect (Huguet et al., 2009; Marsh and Parker, 1984). These reference group effects are normally thought to influence students indirectly through their self-evaluation, which correlates with achievement. Alternatively, and as was examined in this paper, an individual's propensity for receiving a grammar school recommendation could be affected more directly. If, when deciding which recommendation to make for a given pupil, a teacher compares this pupil with his or her peers, then the pupil's chances are directly dependent of the classroom context. Given a more or less limited number of places in grammar school and since a recommendation results in a direct transfer to this advantageous school track, we argued that the likelihood of receiving a recommendation is affected by the number of other students with grammar school ambitions. 
To test our assumption, we analysed data from a modified choice experiment and additional data collected in a survey of 70 (prospective) secondary school teachers in Bern, Switzerland. Using logistic regression models with a teacher random effect, we find that the more students plan to attend grammar school, the lower the individual chances of obtaining a recommendation. We also show how this effect is mediated by the share of classmates the teacher deems fit for grammar school, so that the individual propensity for a recommendation decreases with a higher share of classmates the teacher recommends for this highest track. This effect, which is particularly relevant in larger groups of ambitious students, confirms the assumed competition mechanism. Against the background of a more or less fixed number of available places in grammar schools in the short run (an argument that is backed by a constant distribution of students among the different tracks of secondary school in Switzerland over the last 30 years-Federal Statistical Office, 2017), this result suggests that teachers take into account the (perceived) 'demand side' needs and fill up places accordingly.

However, the results are based on a small sample and although almost all respondents have teaching experience in either primary or secondary school, they are all still in education. A straightforward generalization to the wider population of secondary school teachers is therefore not possible. However, we also argued that, if anything, this should lead to an underestimation of the documented effects since teachers in training have a fresh knowledge of the mechanisms behind educational inequalities. They can thus be expected to be particularly aware and might become less so the more time passes and the more they settle into their routines. Moreover, the outlined processes are caused both by the structure of the education system (the static nature of a tracked system) and the comparisons teachers make when deciding whether or not to recommend a student. It is also worthwhile stressing that the teachers in our sample differ considerably in their recommendation decisions (indicated by the significant random effect). This means that aside from individual abilities and that of one's peers, a student's educational chances also depend on the teacher making the decision.

On the whole, we find strong evidence for reference group effects that work by affecting teachers' decisions. By comparing a student with his or her immediate peer group, teachers have a more or less favourable frame of reference. This finding not only 
offers an alternative explanation for the often reported compositional effects on students' educational achievement and attainment, but it also points to an additional mechanism of educational inequalities in tracked education systems (Breen and Goldthorpe, 1997). Our findings imply that next to the often documented primary effects of social origin on students' educational achievement (Becker, 2003; Stocké, 2007) students of lower social origin will additionally be disadvantaged when they face many highperforming peers-especially in larger groups. Irrespective of social origin, however, such reference group effects on teachers' decision making can be regarded as problematic since they affect educational chances beyond the individual effort, motivation and even performance levels of students and are thus out of line with the meritocratic ideal.

\section{References}

Alexander, C.N., Campbell, E.Q., 1964. Peer Influences on Adolescent Educational Aspirations and Attainments. American Sociological Review 29, 568.

Alexander, K., Eckland, B.K., 1975. Contextual Effects in the High School Attainment Process. American Sociological Review 40, 402-416.

Alicke, M.D., Zell, E., Bloom, D.L., 2010. Mere Categorization and the Frog-Pond Effect. Psychological Science 21, 174-177.

Allison, P.D., 2009. Fixed Effects Regression Models. Number 160 in Quantitative Applications in the Social Science, Sage, Thousand Oaks.

Becker, R., 2003. Educational Expansion and Persistent Inequalities of Education. European Sociological Review 19, 1-24.

Boone, S., Thys, S., Van Avermaet, P., Van Houtte, M., 2018. Class composition as a frame of reference for teachers? The influence of class context on teacher recommendations. British Educational Research Journal 44, 274-293. doi:10.1002/berj . 3328 .

Boone, S., Van Houtte, M., 2013. Why are teacher recommendations at the transition from primary to secondary education socially biased? A mixed-methods research. British Journal of Sociology of Education 34, 20-38. URL: http:// 
www. tandf online.com/doi/abs/10.1080/01425692.2012.704720, doi:10 . $1080 / 01425692.2012 .704720$.

Breen, R., Goldthorpe, J.H., 1997. Explaining Educational Differentials: Towards a formal rational action theory. Rationality and Society 9, 275-305.

Cameron, C.A., Trivedi, P.K., 2005. Microeconometrics. Methods and Applications. Cambridge University Press, Cambridge.

Clarke, P., Crawford, C., Steele, F., Vignoles, A., 2015. Revisiting fixed- and randomeffects models: some considerations for policy-relevant education research. Education Economics 23, 259-277. doi:10 .1080/09645292 . 2013.855705.

Davis, J.A., 1966. The Campus as a Frog Pond: An Application of the Theory of Relative Deprivation to Career Decisions of College Men. American Journal of Sociology $72,17-31$.

Dockx, J., De Fraine, B., Vandecandelaere, M., 2019. Tracks as frames of reference for academic self-concept. Journal of School Psychology 72, 67-90. doi:10 . 1016/ j.jsp.2018.12.006.

Erikson, R., Jonsson, J.O., 1996. Explaining Class Inequality in Education. The Swedish Test Case, in: Erikson, R., Jonsson, J.O. (Eds.), Can Education Be Equalized? The Swedish Case in Comparative Perspective. Westview Press, Boulder, Colorado, pp. 1-63.

Erziehungsdirektion des Kantons Bern, 2017. Gemeinsame Grundlagenformulare GYM1, FMS, WMS, BM 1, IMS.

Federal Statistical Office, 2017. Selektion auf der Sekundarstufe I nach Schultyp. URL: https://www.bfs.admin.ch/bfs/de/home/ statistiken/bildung-wissenschaft/bildungsindikatoren/ bildungssystem-schweiz/themen/bildungsverlaeufe/ selektion-sekundarstufe.assetdetail.2924648.html. 
Gröhlich, C., Guill, K., 2009. How stable are reference group effects of secondary school track recommendations? Journal for Educational Research Online 1, 154171.

Haller, A.O., Portes, A., 1973. Status Attainment Process. Sociology of Education 46, $51-91$

Hanushek, E.A., Kain, J.F., Markman, J.M., Rivkin, S.G., 2003. Does Peer Ability Affect Student Achievement? Journal of Applied Econometrics 18, 527-544.

Hoge, R.D., Coladarci, T., 1989. Teacher-Based Judgments of Academic Achievement: A Review of Literature. Review of Educational Research 59, 297. URL: http://links.jstor.org/sici?sici=0034-6543\% $28198923 \% 2959 \% 3$ A3\%3C297\%3ATJOAAA\%3E2 . 0 . CO\%3B2-T\&origin=crossref, doi:10.2307/1170184.

Hox, J.J., 2010. Multilevel Analysis: Techniques and Applications. Routledge, New York.

Huguet, P., Dumas, F., Marsh, H., Régner, I., Wheeler, L., Suls, J., Seaton, M., Nezlek, J., 2009. Clarifying the role of social comparison in the big-fish-little-pond effect (BFLPE): An integrative study. Journal of Personality and Social Psychology 97, 156-170. URL: http://doi .apa.org/getdoi.cfm?doi=10.1037/a0015558, doi:10.1037/a0015558.

Imberman, S.A., Kugler, A.D., Sacerdote, B.I., 2012. Katrina's children: Evidence on the structure of peer effects from hurricane evacuees. The American Economic Review 102, 2048-2082.

Jussim, L., Harber, K.D., 2005. Teacher expectations and self-fulfilling prophecies: Knowns and unknowns, resolved and unresolved controversies. Personality and Social Psychology Review 9, 131-155.

Klapproth, F., Fischer, B.D., 2018. Preservice teachers' evaluations of students' achievement development in the context of school-track recommendations. European Journal of Psychology of Education doi:10.1007/s10212-018-0405-x. 
Krueger, A.B., 1999. Experimental estimates of education production functions. The Quarterly Journal of Economics 114, 497-532.

Maaz, K., Trautwein, U., Lüdtke, O., Baumert, J., 2008. Educational transitions and differential learning environments: How explicit between-school tracking contributes to social inequality in educational outcomes. Child Development Perspectives 2, 99-106.

Marsh, H.W., 1987. The Big-Fish-Little-Pond Effect on Academic Self-Concept. Journal of Educational Psychology 79, 280-295.

Marsh, H.W., Hau, K.T., 2003. Big-Fish-Little-Pond effect on academic self-concept: A cross-cultural (26-country) test of the negative effects of academically selective schools. American Psychologist 58, 364-376. doi:10.1037/0003-066X.58.5. 364.

Marsh, H.W., Parker, J.W., 1984. Determinants of Student Self-Concept: Is It Better to Be a Relatively Large Fish in a Small Pond Even if You Don't Learn to Swim as Well? Journal of Personality and Social Psychology 47, 213-231.

Palardy, G.J., 2008. Differential school effects among low, middle, and high social class composition schools: a multiple group, multilevel latent growth curve analysis. School Effectiveness and School Improvement 19, 21-49. doi:10.1080/ 09243450801936845.

Rist, R., 1970. Student social class and teacher expectations: The self-fulfilling prophecy in ghetto education. Harvard Educational Review 40, 411-451.

Rumberger, R.W., Palardy, G.J., 2005. Does segregation still matter? The impact of student composition on academic achievement in high school. Teachers College Record 107, 1999-2045.

Sacerdote, B., 2001. Peer Effects with Random Assignment: Results for Dartmouth Roommates. The Quarterly Journal of Economics 116, 681-704. 
Sacerdote, B., 2011. Peer Effects in Education: How Might They Work, How Big Are They and How Much Do We Know Thus Far?, in: Hanushek, E.A., Machin, S., Woessmann, L. (Eds.), Handbook of the Economics of Education. Elsevier, Amsterdam. volume 3, pp. 249-278.

Sewell, W.H., Haller, A.O., Portes, A., 1969. The Educational and Early Occupational Attainment Process. American Sociological Review 34, 82-92.

Stocké, V., 2007. Explaining Educational Decision and Effects of Families' Social Class Position: An Empirical Test of the Breen Goldthorpe Model of Educational Attainment. European Sociological Review 23, 505-519.

Street, D.J., Burgess, L., 2007. The construction of optimal stated choice experiments. Theory and Methods. Wiley series in probability and statistics, Wiley, Hoboken, N.J.

Thrupp, M., Lauder, H., Robinson, T., 2002. School composition and peer effects. International Journal of Educational Research 37, 483-504.

Trautwein, U., Lüdtke, O., Marsh, H.W., Köller, O., Baumert, J., 2006. Tracking, grading, and student motivation: Using group composition and status to predict selfconcept and interest in ninth-grade mathematics. Journal of Educational Psychology 98, 788-806. doi:10.1037/0022-0663.98.4.788.

Williams, R., 2012. Using the margins command to estimate and interpret adjusted predictions and marginal effects. The Stata Journal 12, 308-331.

Wooldridge, J.M., 2003. Cluster-Sample Methods in Applied Econometrics. The American Economic Review 93, 133-138.

Wooldridge, J.M., 2010. Econometric Analysis of Cross Section and Panel Data. The MIT Press, Cambridge MA.

Wyse, A.E., Keesler, V., Schneider, B., 2008. Assessing the effects of small school size on mathematics achievement: A propensity score-matching approach. The Teachers College Record 110, 1879-1900. 
Zell, E., Alicke, M.D., 2009. Contextual neglect, self-evaluation, and the frog-pond effect. Journal of Personality and Social Psychology 97, 467-482. URL: http: // doi . apa .org/getdoi. cfm?doi=10.1037/a0015453, doi:10.1037/a0015453.

Zimmerman, D.J., 2003. Peer effects in academic outcomes: Evidence from a natural experiment. Review of Economics and Statistics 85, 9-23.

\section{Appendix A.}

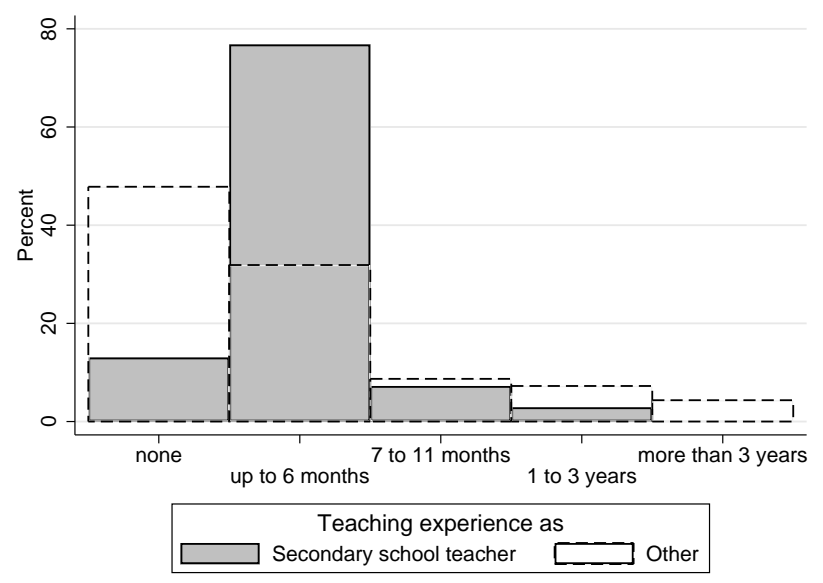

Figure A1: Respondents' teaching experience 


\begin{tabular}{lcccc}
\hline \hline & Mean & SD & Min & Max \\
\hline Experiment & 5.123 & 0.416 & 4.5 & 5.5 \\
Grade last semester & 1.015 & 0.814 & 0 & 2 \\
Performance & 0.484 & 0.500 & 0 & 1 \\
Participation during class & 0.521 & 0.500 & 0 & 1 \\
Learning and study habits & 0.498 & 0.500 & 0 & 1 \\
Methods and ways of working & 0.515 & 0.500 & 0 & 1 \\
Parental education & 0.412 & 0.492 & 0 & 1 \\
Parental aspirations & 0.496 & 0.500 & 0 & 1 \\
Student's gender & 0.412 & 0.492 & 0 & 1 \\
Subject & 4.167 & 0.800 & 3 & 5 \\
Group size & & & & \\
Teacher Characteristics & 2.000 & 0.569 & 1 & 4 \\
Experience as secondary teacher & 2.882 & 1.132 & 0 & 4 \\
Knowledge recommendation & 0.515 & 0.500 & 0 & 1 \\
Gender (Reference: man) & 0.235 & 0.424 & 0 & 1 \\
Migration background (Reference: none) & 1.574 & 0.626 & 1 & 3 \\
Subjective social status & \multicolumn{5}{c}{$816(68)$} \\
\hline N (Teacher)
\end{tabular}

* After listwise deletion of 24 vignettes (2 respondents) with item-nonresponse.

Table A1: Descriptive Statistics 


\begin{tabular}{|c|c|c|c|c|}
\hline & $\begin{array}{c}(1) \\
\text { Baseline }\end{array}$ & $\begin{array}{c}(2) \\
\text { Controls }\end{array}$ & $\begin{array}{c}(3) \\
\text { Mediator }\end{array}$ & $\begin{array}{c}(4) \\
\text { Interaction }\end{array}$ \\
\hline Grade last semester & $\begin{array}{l}0.538^{* * *} \\
(0.009)\end{array}$ & $\begin{array}{l}0.540^{* * *} \\
(0.009)\end{array}$ & $\begin{array}{l}0.553^{* * *} \\
(0.014)\end{array}$ & $\begin{array}{c}0.553^{* * *} \\
(0.014)\end{array}$ \\
\hline \multicolumn{5}{|c|}{ Participation (Reference: active) } \\
\hline not active & $\begin{array}{l}-0.091^{* * *} \\
(0.024)\end{array}$ & $\begin{array}{c}-0.092^{* * *} \\
(0.024)\end{array}$ & $\begin{array}{l}-0.092^{* * *} \\
(0.024)\end{array}$ & $\begin{array}{l}-0.092^{* * *} \\
(0.024)\end{array}$ \\
\hline \multicolumn{5}{|c|}{ Learning \& study habits (Reference: learns new things easily) } \\
\hline needs some time & $\begin{array}{c}-0.071^{* *} \\
(0.025)\end{array}$ & $\begin{array}{c}-0.070^{* *} \\
(0.024)\end{array}$ & $\begin{array}{c}-0.072^{* *} \\
(0.024)\end{array}$ & $\begin{array}{c}-0.072^{* *} \\
(0.024)\end{array}$ \\
\hline \multicolumn{5}{|c|}{ Methods and learning style (Reference: independent $\mathcal{E}$ concentrated) } \\
\hline $\begin{array}{l}\text { not very independent \& } \\
\text { rather not concentrated }\end{array}$ & $\begin{array}{l}-0.189^{* * *} \\
(0.024)\end{array}$ & $\begin{array}{l}-0.188^{* * *} \\
(0.024)\end{array}$ & $\begin{array}{l}-0.189^{* * *} \\
(0.024)\end{array}$ & $\begin{array}{l}-0.189^{* * *} \\
(0.024)\end{array}$ \\
\hline Group size & $\begin{array}{r}-0.024 \\
(0.015)\end{array}$ & $\begin{array}{r}-0.025^{+} \\
(0.015)\end{array}$ & $\begin{array}{r}-0.028^{+} \\
(0.015)\end{array}$ & $\begin{array}{r}-0.028^{+} \\
(0.015)\end{array}$ \\
\hline \multicolumn{2}{|c|}{ Share classmates with recommendation } & & $\begin{array}{c}0.094 \\
(0.077)\end{array}$ & $\begin{array}{c}0.091 \\
(0.079)\end{array}$ \\
\hline Teacher: experience $\&$ kn & & $\checkmark$ & $\checkmark$ & $\checkmark$ \\
\hline \multicolumn{2}{|c|}{ Teacher: background characteristics } & $\checkmark$ & $\checkmark$ & $\checkmark$ \\
\hline Pseudo $\mathrm{R}^{2}$ & 0.405 & 0.413 & 0.415 & 0.415 \\
\hline $\mathrm{N}$ & & & 16 & \\
\hline
\end{tabular}

Marginal effects; Standard errors in parentheses

(d) for discrete change of dummy variable from 0 to 1

${ }^{+} p<0.1,{ }^{*} p<0.05,{ }^{* *} p<0.01,{ }^{* * *} p<0.001$

Table A2: Logit with clustered SE (being recommended for grammar school) 


\begin{tabular}{|c|c|c|c|}
\hline \multirow{2}{*}{ Grade last semester } & $\begin{array}{c}(1) \\
\text { Baseline }\end{array}$ & $\begin{array}{c}(2) \\
\text { Mediator }\end{array}$ & $\begin{array}{c}\text { (3) } \\
\text { Interaction }\end{array}$ \\
\hline & $\begin{array}{l}192.779^{* * *} \\
(75.342)\end{array}$ & $\begin{array}{l}102.060^{* * *} \\
(41.477)\end{array}$ & $\begin{array}{l}105.313^{* * *} \\
(43.925)\end{array}$ \\
\hline \multicolumn{4}{|c|}{ Participation (Reference: active) } \\
\hline not active & $\begin{array}{l}0.459^{* * *} \\
(0.108)\end{array}$ & $\begin{array}{c}0.465^{* *} \\
(0.119)\end{array}$ & $\begin{array}{c}0.465^{* *} \\
(0.122)\end{array}$ \\
\hline \multicolumn{4}{|c|}{ Learning \& study habits (Reference: learns new things easily) } \\
\hline needs some time & $\begin{array}{c}0.496^{* *} \\
(0.117)\end{array}$ & $\begin{array}{c}0.519^{* *} \\
(0.131)\end{array}$ & $\begin{array}{r}0.538^{*} \\
(0.137)\end{array}$ \\
\hline \multicolumn{4}{|c|}{ Methods and learning style (Reference: independent $\mathcal{F}$ concentrated) } \\
\hline $\begin{array}{l}\text { not very independent \& } \\
\text { rather not concentrated }\end{array}$ & $\begin{array}{l}0.169^{* * *} \\
(0.044)\end{array}$ & $\begin{array}{l}0.177^{* * *} \\
(0.050)\end{array}$ & $\begin{array}{l}0.171^{* * *} \\
(0.050)\end{array}$ \\
\hline Group size & $\begin{array}{l}0.788^{+} \\
(0.110)\end{array}$ & $\begin{array}{c}0.829 \\
(0.121)\end{array}$ & $\begin{array}{r}2.915^{*} \\
(1.309)\end{array}$ \\
\hline \multicolumn{2}{|c|}{ Share classmates with recommendation } & $\begin{array}{l}0.001^{* * *} \\
(0.001)\end{array}$ & $\begin{array}{c}17.018 \\
(57.524)\end{array}$ \\
\hline \multicolumn{2}{|c|}{ Share transition * group size } & & $\begin{array}{c}0.077^{* *} \\
(0.068)\end{array}$ \\
\hline $\mathrm{N}$ & & 816 & \\
\hline
\end{tabular}

Odds ratios; Standard errors in parentheses

(d) for discrete change of dummy variable from 0 to 1

${ }^{+} p<0.1,{ }^{*} p<0.05,{ }^{* *} p<0.01,{ }^{* * *} p<0.001$

Table A3: Fixed effect models (being recommended for grammar school) 